REGARDS

SUR LEECONOMIE ALLEMANDE

BULLETIN ECONOMIQUE DU CRAC

\section{Regards sur l'économie allemande}

Bulletin économique du CIRAC

$90 \mid 2009$

Varia

\title{
Société du savoir
}

KEELEY Brian, Le capital humain. Comment le savoir détermine notre vie

\section{OpenEdition}

\section{Journals}

Édition électronique

URL : http://journals.openedition.org/rea/3603

DOI : $10.4000 /$ rea.3603

ISBN : 978-2-8218-0876-8

ISSN : 1965-0787

\section{Éditeur}

CIRAC

Édition imprimée

Date de publication : 1 mars 2009

ISSN : 1156-8992

Référence électronique

"Société du savoir », Regards sur l'économie allemande [En ligne], 90 | mars 2009, mis en ligne le 25 mars 2009, consulté le 22 septembre 2020. URL : http://journals.openedition.org/rea/3603 ; DOI : https://doi.org/10.4000/rea.3603

Ce document a été généré automatiquement le 22 septembre 2020

(C) CIRAC 


\section{Société du savoir}

KEELEY Brian, Le capital humain. Comment le savoir détermine notre vie

\section{RÉFÉRENCE}

KEELEY Brian, Le capital humain. Comment le savoir détermine notre vie, Les essentiels de l'OCDE, Editions OCDE, Paris, 2007, 159 p.

1 La mondialisation de la production industrielle, portant atteinte à l'emploi peu qualifié dans les pays développés, ainsi que l'avènement de la société du savoir, ont pour corollaire l'évolution constante des compétences requises sur le marché du travail dans des sociétés par ailleurs en proie au vieillissement démographique. Dans ce contexte, les membres de l'OCDE ont depuis longtemps saisi les enjeux de la valorisation du capital humain qui, selon l'organisation, "recouvre les connaissances, les qualifications, les compétences et les autres qualités d'un individu qui favorisent le bien-être " non seulement économique, mais aussi personnel et social. La présente analyse inaugure le lancement de la collection Les essentiels de l'OCDE, dont la vocation est de sensibiliser un plus large public à ses travaux. Elle ne prétend nullement à l'exhaustivité : libre au lecteur de poursuivre ou non ses recherches à la faveur des nombreuses références citées en fin d'ouvrage... (sh) 